\title{
OPEN Effect of milk-derived bioactive peptides on the lipid stability and functional properties of beef nuggets
}

\author{
Muhammad Sajid Arshad ${ }^{1 凶}$, Gule Hina ${ }^{1}$, Faqir Muhammad Anjum ${ }^{2}$ \& \\ Hafiz Ansar Rasul Suleria ${ }^{3}$
}

The present study was conducted to ascertain the beneficial effects of bioactive peptides on the oxidative stability and functional properties of beef nuggets. In this study, milk casein protein hydrolysates were extracted and incorporated into beef nuggets which were then subjected to different assessment parameters including oxidative stability, functional capability as well as microbial and physico-chemical quality tests were performed for determining the meat quality at different storage periods. The casein protein hydrolysate powder $(\mathrm{CPH})$ was added at different concentrations in nuggets $\mathrm{CPH} 2 \%, 4 \%, 6 \%$ and $8 \%$, with reference to storage period of $0,5,10$ and 15 days at $4{ }^{\circ} \mathrm{C}$. The results regarding total phenolic contents (TPC) and DPPH free radical scavenging assay showed a significant increased with respect to $\mathrm{CPH}$ powder and significantly decreased with respect to storage interval. The TVBN, TBARS and POV of the CPH powder incorporated raw beef nuggets also differed significantly within groups with storage time. Higher POV and TBARS were noticed in the CPH $8 \%$ incorporated beef nuggets. However, the raw beef nuggets that were made by the incorporation $8 \% \mathrm{CPH}$ powder, maintained significantly lower level of TBARS at the end of the storage period in contrast with the levels of the control (CPH 0\%). The results of the $\mathrm{pH}$ and Hunter color test also showed a significant difference with respect to different groups. The microbiological analysis of beef nuggets showed a significant decrease in the level of both the total aerobic and coliform counts and also indicated a decreasing trend in the level of contamination by these bacteria within the groups. This depicted that the casein protein hydrolysate powder (CPH) or simply, the peptide powder has the strong ability to decrease lipid oxidation and related shelf-life retarding natural processes occurring in the meat. It can also greatly enhance the functional properties of the raw meat (beef) and meat products. Thus, it is seen that the bioactive peptides (BAP's) are a key factor in improving the oxidative stability and functional properties of beef nuggets.

Bioactive peptides (BAP's) are known to be as specific organic compounds (proteins) that have a positive impact on body function or conditions that influence on health. Currently, over 1500 totally different BAP's are reported in an outstanding gen named as 'Bio-pep'.

Bioactive peptides are organic substances made by amino acids (2-20 amino acids) joined by covalent bonds also known as amide or peptide bonds. Proteins are polypeptides with a greater molecular weight (MW). Bioactive peptides and proteins play vivacious roles in the metabolic functions of living organisms and hence in human health. They exhibit hormone or drug-like activities and can be categorized based on their mode of action as antimicrobial, anti-oxidative, anti-obesity, anti-diabetic, anti-thrombotic, antihypertensive, opioid, immunemodulatory, anticancer, minerals binding and probiotic properties. Consequently, they are released through food processing (fermentation, aging, enzymatic treatment) or during digestion ${ }^{2}$.

Bioactive peptides, commonly known as BAP's have been appraised as the new generation of biologically active regulators that can halt for example oxidation and microbial degradation taking place in foods. By far, buffalo and bovine milk and dairy products are the significant sources of bioactive proteins and peptides acquired

\footnotetext{
${ }^{1}$ Department of Food Science, Faculty of Life Sciences, Government College University, Faisalabad, Pakistan. ${ }^{2}$ University of the Gambia, Serrekunda, The Gambia. ${ }^{3}$ School of Agriculture and Food, Faculty of Veterinary and Agricultural Sciences, The University of Melbourne, Parkville, VIC 3052, Australia. ${ }^{\bowtie}$ email: sajid_ ft@yahoo.com
} 
from foods. They can also be derived from other animal sources such as bovine blood ${ }^{3}$, gelatin, meat, eggs and various fish species such as tuna, sardine, herring and salmon. Some vegetal sources of BP and proteins are wheat, maize, soy, rice, mushrooms, pumpkin, sorghum and amaranth ${ }^{4,5}$. Milk proteins possess an ample range of biological activities. For example, immunoglobulins exhibit potent immuno-protective result and lactoferrin (Lf) exhibits medicine activity. Low concentrations of growth factors and hormones, mainly present in colostrum, appear to play an important role in post-natal development ${ }^{6}$.

Most of the functional bioactive peptides are bent in convoluted matrices, consist of variety of hydrolyzed super molecule fractions, their separation and purification are one of the important challenges and are required to study at molecular level. Conventional pressure-driven processes are generally used for amino acids and peptides separation but are restricted by their fouling problems and their low property once separating similar sized biomolecules. In recent times, electro-dialysis using ultra-filtration membranes has been established to fractionate concurrently acidic and basic peptides using a conventional electro-dialysis cell where ion exchange membranes are substituted by ultra-filtration ${ }^{7}$.

Using liquid chromatography-mass spectrometry (HPLC-MS) and tandem mass spectrometry (MS), a large number of medium and low-MW BAP's (including opioid and phosphopeptides) were recognized in human milk from mothers of pre and full-term infants. The development of many peptides ratifies the larger susceptibility of human milk to casein proteolysis compared to bovine milk. Fermentation of milk proteins mistreatment carboxylic acid bacterium (LAB) is an appealing approach to come up with purposeful foods supplemented with $\mathrm{BP}$ given the low price and positive organic process image allied with fermented milk products ${ }^{8}$.

However, some discrepancies on the nature of BAP's depending on the milk protein source, the isolation, and categorization of peptides of different bioactivities from milk protein hydrolysates and products of buffalo, camel, goat, mare, sheep, and yak milk have already been informed ${ }^{9}$. Bioactive peptides having high antioxidant activity are gained from fermented food products through the action of different beneficial micro-organisms and endogenous proteolytic enzymes ${ }^{10,11}$.

Bioactive peptides are claimed to prevent lipid oxidation in meat and other products; in addition, these antioxidant peptides have also been reported to possess substantial health-promoting potential besides controlling oxidation. Peptides derived from milk proteins have shown antioxidant properties that prevent the per-oxidation of essential fatty acids. Whey as well as casein protein hydrolysates have been shown to inhibit lipid oxidation in muscle foods ${ }^{12}$.

The antioxidative potential of peptides can be accredited to their metal ion-chelation, lipid per-oxidation inhibition, and radical-scavenging properties. It also has been documented that the structure of peptides with its amino acid sequence can influence their anti-oxidative potential ${ }^{13}$. Thus, peptides and proteins have tremendous potential as antioxidants for food, especially in meat and meat products ${ }^{14}$. Keeping in view the above features the objectives set to be attained for present research includes the extraction of milk peptides and their incorporation in meat and assessing the effect of these bioactive peptides on the functional parameters of meat and evaluating the oxidative stability of meat in response to the addition of bioactive peptides.

\section{Materials and methods}

Procurement of raw materials. Beef was sourced from the superstore (METRO, Pakistan) and this meat was then ground finely for further use. The ground beef samples were then stored in an airtight bag for further study. The milk-protein isolates (MPIs) had a dry basis purity of $90 \%$. The different standards and reagents used were purchased from renowned companies like Sigma-Aldrich (Tokyo, Japan) and Merck (Merck KGaA and Darmstadt, Germany).

Preparation of milk protein hydrolysates. According to the peptide guidelines of ${ }^{15}$, three different types of microbial proteases namely the effective enzyme Validase (Val), Alkaline Protease (AP) and Neutral Protease (NP) were used to hydrolyze the milk protein isolates. Thus, an estimated amount of $50 \mathrm{~g}$ of milk protein was homogenized in $500 \mathrm{~mL}$ of water and it was hydrolyzed by each protease at a concentration of about $2 \%$ (w/w, enzyme/substrate). The enzymatic hydrolysis was carried out in a water bath for $6 \mathrm{~h}$, and the mixture was shaken at $55^{\circ} \mathrm{C}$. The mixture was centrifuged at $15,000 \mathrm{~g}$ and the remaining soluble fraction was filtered using Whatman filter paper for further classification.

Separation of protein hydrolysates by ultra-filtration. The casein hydrolysate prior to dilution with distilled water was ultra-filtered using the protocol of ${ }^{15}$ for a nominal molecular weight limit (NMWL) of $10 \mathrm{kD}$ membrane under a pressure of $40 \mathrm{psi}$, utilizing nitrogen. As a result of this process, two fractions retentate and permeate were obtained. The entire retentate and permeate were lyophilized and stored at $-20{ }^{\circ} \mathrm{C}$ for further analysis.

Preparation of CPH powder. For the preparation of buffalo milk casein protein hydrolysate (CPH) powder, the method described earlier by Kumar et al. ${ }^{16}$ was made in use. In short, the casein protein hydrolysate $(\mathrm{CPH})$ powder containing almost $5 \%$ of the total solids and which was already freeze-dried, was made to dissolve for the highest optimum enzymatic action within the phosphate buffer having a $\mathrm{pH} 8.0$ and then about 1:100 (Enzyme: Substrate ratio) of alkaline protease was added to it. Afterwards, by incubating the sample at an unceasing temperature of $55^{\circ} \mathrm{C}$, the process of hydrolysis was conducted in a stirred water-bath for a period of $6 \mathrm{~h}$. The sample obtained after the completion of hydrolysis was then heated rapidly to about $85^{\circ} \mathrm{C}$ in a waterbath aimed at $15 \mathrm{~min}$, in order to denature the residual enzyme in it. After this, the sample was cooled down and instantaneously centrifuged at $11,200 \times \mathrm{g}$ in a refrigerated centrifuge machine for $25 \mathrm{~min}$ and the subsequent supernatant was then collected and stored. It was then dried in a vacuum oven at $600 \mathrm{mmHg}$ vacuum and then 
oven was run at $50^{\circ} \mathrm{C}$ for the duration of about $12-14 \mathrm{~h}$. The supernatant was ground in the form of a fine powder and it was kept at $-20^{\circ} \mathrm{C}$ till its next use.

Formulation of meat nuggets. The peptide powder thus formed was added in meat that was then made into nugget each weighing $16 \mathrm{~g}$ at different concentrations. The formed nuggets were then packed in zipper bags and stored at refrigeration temperature following the protocols of ${ }^{17}$. Composition of peptide powder incorporate raw beef nuggets: five treatment groups were made and each group contained the casein protein hydrolysate $(\mathrm{CPH})$ powder in quantities as $\mathrm{CPH} 0 \%$, made without the incorporation of peptide powder regarded as the control sample, $\mathrm{CPH} 2 \%$ containing $2 \%$ peptide powder, $\mathrm{CPH} 4 \%$ containing $4 \%$ peptide powder, $\mathrm{CPH} 6 \%$ and $\mathrm{CPH} 8 \%$ containing $6 \%$ and $8 \%$ protein peptide powder respectively. The treatments were then subjected to various functional capability and oxidative stability tests at $0,5,10$ and 15 days interval.

Total phenolic contents (TPCs). The TPC content in the beef nuggets was calculated by using the FolinCiocalteu method as defined in our previous published method of Suleria et al. ${ }^{18} .25 \mu \mathrm{L}$ extract and same amount of Folin-Ciocalteu reagent solution (1:3 diluted with water) respectively and $200 \mu \mathrm{L}$ of water added in plate having 96 well. The prepared mixture was shifted for the incubation for $5 \mathrm{~min}$ in the dark room at controlled temperature $\left(\sim 25^{\circ} \mathrm{C}\right) .25 \mu \mathrm{L}$ of $10 \%(\mathrm{w}: \mathrm{w})$ sodium carbonate was added into the reaction mixture and then shifted for incubation in dark room for $1 \mathrm{~h}$ at $25^{\circ} \mathrm{C}$. Spectrometer used for absorbance and measured at $765 \mathrm{~nm}$. Gallic acid standard in concentrate form having range of $0-200 \mu \mathrm{g} / \mathrm{mL}$ was used to prepare the standard curve, gallic acid TPC content was expressed in mg equivalents/g on the basic of fresh weight (f.w.) (mg GAE/g of sample).

Antioxidant capability using DPPH. The beef patties samples made with CPH powder were subjected to analysis of the DPPH radical scavenging activity according to the procedure outlined by Brand-Williams et al. ${ }^{19}$. The antioxidant activity of the homogenized meat samples were assessed by measuring their scavenging abilities to DPPH stable radicals. A sample of $125 \mu \mathrm{L}$ was mixed with $0.0012 \mathrm{~m} \mathrm{DPPH}$ solution followed by the addition of $95 \% \mathrm{MeOH}$ up to a final volume of $4 \mathrm{~mL}$ and allowed to rest for $1 \mathrm{~h}$ at room temperature. The absorbance of the resulting solution and the blank were recorded spectrophotometrically at $515 \mathrm{~nm}$. The inhibition of free radicals by DPPH in percent (\%) was calculated by using the following formula.

$$
\text { Inhibition }(\%)=100 \times(\text { Absorbance blank }- \text { Absorbance sample/Absorbance blank })
$$

Total volatile basic nitrogen (TVBN). The TVBN value of beef nuggets was measured by following the method of An et al. ${ }^{20}$ with some modification. Homogenization of $5 \mathrm{~g}$ meat sample was done in $45 \mathrm{ml}$ distilled water for $30 \mathrm{~s}$ and $5 \mathrm{ml}$ of the prepared homogenate was used to mix with an equal volume of $10 \%$ trichloroacetic acid (TCA; w/v in distilled water). For the determination of TVBN Value prepared TCA were used. $1 \mathrm{ml}$ of TVBN reagent used for inner well and the same amount used for outer well of the Conway unit by following the usage of $1 \mathrm{ml}$ saturated potassium carbonate $\left(\mathrm{K}_{2} \mathrm{CO}_{3}\right)$. After that, Conway unit was closed using airtight ground glass plate, and then shifted for the incubation at controlled temperature for $3 \mathrm{~h}$. TVBN reagent was again titrated using $0.02 \mathrm{~N}\left(\mathrm{H}_{2} \mathrm{SO}_{4}\right)$ till blue color converted into pink. Following equation was used for the calculation of TBVN value.

$$
\begin{gathered}
\text { "N" mg/ml of extract }=14 \times \mathrm{a} \times \mathrm{b} \\
\text { TVBN value }(\mathrm{mg} / 100 \mathrm{ml})=100 \times \mathrm{N} \\
14=\text { molecular weight of nitrogen, } \mathrm{a}=\text { normality of } \mathrm{H}_{2} \mathrm{SO}_{4}, \mathrm{~b}=\text { volume of } \mathrm{H}_{2} \mathrm{SO}_{4} \text {, (titration value). }
\end{gathered}
$$

Peroxide value (POV). Peroxide value was determined according to the method of the International Dairy Federation (IDF) ${ }^{21}$. The iron (II) chloride solution was prepared by using $0.4 \mathrm{~g}$ barium chloride dihydrate dissolved in $50 \mathrm{~mL}$ water. This solution was added slowly and with constant stirring to an iron (II) sulfate solution $\left(0.5 \mathrm{~g} \mathrm{FeSO}_{4} \cdot 7 \mathrm{H}_{2} \mathrm{O}\right.$ dissolved in $50 \mathrm{~mL}$ water). (1) $2 \mathrm{~mL}$ of $10 \mathrm{~N} \mathrm{HCl}$ was added to the resulting solution. (2) The barium sulfate precipitate was filtered off to give a clear iron (II) solution, which was stored in a brown bottle and kept in the dark. The ammonium thiocyanate solution was prepared as under: $30 \mathrm{~g}$ ammonium thiocyanate was dissolved in water, and the volume was made up to $100 \mathrm{~mL}$. The samples $(0.2 \mathrm{~g})$ was homogenized with $9.8 \mathrm{~mL}$ of cold phosphate buffer ( $40 \mathrm{mM}, \mathrm{pH}$ 6.8) for $10 \mathrm{~s}$ at 13,000 rpm, then mixed in a disposable glass tube with $9.8 \mathrm{~mL}$ chloroform-methanol $(7: 3, \mathrm{v} / \mathrm{v})$ on a vortex mixer for $2-4 \mathrm{~s}$, then added ammonium thiocyanate solution (50 $\mu \mathrm{L}$ ) and the sample was vortex-mixed for 2-4 s, then added $50 \mu \mathrm{L}$ iron (II) solution and the sample was again vortex-mixed for 2-4 s, After 5 min incubation at room temperature, the absorbance of the sample was determined at $500 \mathrm{~nm}$ against a blank that contained all the reagents except the sample by using a spectrophotometer.

The entire procedure was conducted in subdued light and completed within $10 \mathrm{~min}$.

$$
\text { Peroxide value }=\frac{\left(\mathrm{A}_{\mathrm{s}}-\mathrm{A}_{\mathrm{b}}\right) \times \mathrm{m}}{55.84 \times \mathrm{m}_{0} \times 2}
$$

$\mathrm{A}_{\mathrm{s}}=$ Absorbance of the sample, $\mathrm{A}_{\mathrm{b}}=$ Absorbance of the blank, $\mathrm{M}$ (Standard) $=41.52, \mathrm{~m}_{0}=$ mass in gram, $55.84=$ atomic weight of iron. 


\begin{tabular}{|c|c|c|c|c|}
\hline \multirow[b]{3}{*}{ Groups } & \multicolumn{4}{|l|}{ TPC (mg GAE/g) } \\
\hline & \multicolumn{4}{|l|}{ Storage days } \\
\hline & 0 & 5 & 10 & 15 \\
\hline Control & $95.66 \pm 2.41 \mathrm{eB}$ & $102.00 \pm 2.00 \mathrm{eA}$ & $101.50 \pm 1.91 \mathrm{eA}$ & $92.00 \pm 1.99 \mathrm{eC}$ \\
\hline $\mathrm{CPH} 2 \%$ & $110.00 \pm 2.22 \mathrm{~dB}$ & $114.50 \pm 2.19 \mathrm{dA}$ & $111.00 \pm 2.30 \mathrm{~dB}$ & $109.00 \pm 1.69 \mathrm{dC}$ \\
\hline $\mathrm{CPH} 4 \%$ & $118.50 \pm 2.11 \mathrm{cB}$ & $122.50 \pm 2.20 \mathrm{cA}$ & $117.50 \pm 1.35 \mathrm{cC}$ & $114.50 \pm 1.80 \mathrm{cD}$ \\
\hline $\mathrm{CPH} 6 \%$ & $122.00 \pm 2.10 \mathrm{bB}$ & $128.00 \pm 2.18 \mathrm{bA}$ & $123.50 \pm 1.30 \mathrm{bB}$ & $120.00 \pm 2.66 \mathrm{bC}$ \\
\hline СРH8\% & $126.00 \pm 2.00 \mathrm{aC}$ & $130.50 \pm 2.15 \mathrm{aA}$ & $127.00 \pm 1.35 \mathrm{aB}$ & $124.50 \pm 2.65 \mathrm{aD}$ \\
\hline
\end{tabular}

Table 1. Total phenolic content of casein protein hydrolysate $(\mathrm{CPH})$ incorporated beef nuggets during storage. $\mathrm{CPH}$ : casein protein hydrolysate. All the values are means of triplicate determinations \pm Standard Deviation (SD). Means within the column with different small letters are significantly different $(\mathrm{p}<0.05)$ and different capital letters within the row differed significantly.

Thio-barbituric acid derivative quality test (TBARS). The lipid oxidation in beef patties was measured by using a method of TBARS as described by Ahn et al. ${ }^{22}$. Fifteen milliliters of deionised distilled water (DDW) was added to the beef patties samples $(5 \mathrm{~g})$, and homogenized for $30 \mathrm{~s}$. The homogenate $(1 \mathrm{~mL})$ was transferred to a disposable test tube and $50 \mu \mathrm{L}$ of butylated hydroxytoluene (BHT) and $2 \mathrm{~mL}$ of 2-thiobarbituric acid and trichloracetic acid mixture ( $20 \mathrm{~mL} 20 \mathrm{mM}$ TBA in $15 \%$ trichloroacetic acid) solution were added. After that, the mixture was vortexed and incubated in a boiling water bath for $15 \mathrm{~min}$, then the sample was cooled in cold water for $10 \mathrm{~min}$ and after that the sample was centrifuged for $15 \mathrm{~min}$ at $2500 \times g$ at $4{ }^{\circ} \mathrm{C}$. Then check the absorbance of the resulting supernatant was measured using a UV/VIS spectrophotometer at $532 \mathrm{~nm}$ against a blank containing $1 \mathrm{~mL}$ DW and $2 \mathrm{~mL}$ TBA/TCA solution.

The concentration of malonaldehyde was calculated from the following equation. TBARS values were expressed as $\mathrm{mg}$ malondialdehyde per kg meat.

$$
\text { mg malondialdehydes per kg meat }=\frac{(\text { Sample absorbance }- \text { blank }) \times \text { Total sample vol }}{0.000156 \times 1000} .
$$

Physico-chemical analysis ( $\mathrm{pH}$ and color). The $\mathrm{pH}$ values of beef nuggets were ascertained with a digital pH meter by way of the procedure devised by ${ }^{23}$. The color of beef nuggets was tested by using the Hunter color (Chromameter, CHROMA-400, Pulsed xenon lamp, $400 \mathrm{~nm}$ to $700 \mathrm{~nm}$, Japan) as method of Holmon et al. ${ }^{24}$. The sensor has $14.0 \mathrm{~mm}$ aperture and $45^{\circ}$ measuring geometry. Illuminant $\mathrm{D} 65$ and $10^{\circ}$ standard observer settings were used. The CIE L (light-ness), $\mathrm{a}^{\star}$ (redness) and $\mathrm{b}^{\star}$ (yellowness) values were obtained directly without removing the coating by directly attaching the lens on the surface of the sample. 3 pieces of beef nuggets were measured for each treatment and measured at different locations and this sense 9 data were collected.

Microbial quality determining assays. The microbial counts of the total aerobic bacteria (TAB) and coliforms of the stored beef nuggets were calculated using the methods in accordance with the guidelines of Association of Official Agricultural Chemists ${ }^{25} .10 \mathrm{~g}$ of meat sample was homogenized with $0.1 \%$ of sterile peptone water. Serial dilutions were prepared in $0.1 \%$ peptone water and plated with plate count agar which were incubated at $37^{\circ} \mathrm{C}$ for $48 \mathrm{~h}$. The colonies were counted and expressed as $\log \mathrm{CFU} / \mathrm{g}$.

Statistical analysis. Statistical analysis was performed on the collected data in order to determine the level of significance. The data of different parameters were represented as the means \pm standard deviation and twoway analysis of variance (ANOVA) was used to test for differences in mean values between different samples, followed by Tukey's honestly significant differences (HSD) multiple rank test at $p<0.05$. ANOVA was performed by Minitab Program for Windows version 18.0 elaborated by ${ }^{26}$ (Minitab, LLC, State College, PA, USA).

\section{Results and discussion}

Total phenolic contents (TPC). The incorporation of casein protein hydrolysate (CPH) powder in raw beef nuggets depicted a significant increased $(\mathrm{p}<0.05)$ in total phenolic contents of the beef nuggets (Table 1 ). The results showed that higher TPC value was observed in the group that was incorporated with $8 \% \mathrm{CPH}$ powder, at the beginning of the storage period while the lowest value was shown by the control. The total phenolic contents increased significantly $(\mathrm{p}<0.05)$ within groups, with the increase in $\mathrm{CPH}$ powder and advancement in storage time except for the control group at day 15 . At the end of the storage period, the highest TPC were observed in group having $8 \% \mathrm{CPH}$ powder whereas the lowest amount of TPC was shown by the control at the end of the storage period. It is thus considered that during the course of refrigeration storage $\left(4 \pm 1^{\circ} \mathrm{C}\right)$, the total phenolic contents decreased significantly in all the treatment groups during the storage period but the casein protein hydrolysate powder $(\mathrm{CPH})$ incorporated treatment groups showed a slower rate of decrease than the control, which indicates that the $\mathrm{CPH}$ powder incorporated beef nuggets possess higher oxidative stability than the control. These results are in agreement with the findings of ${ }^{27}$ who reported that a significant decrease in the total phenolic contents of all the fresh chicken sausages and sausage products, at each interval of the storage period. 


\begin{tabular}{|c|c|c|c|c|}
\hline \multirow[b]{3}{*}{ Groups } & \multicolumn{4}{|l|}{ DPPH (\%) } \\
\hline & \multicolumn{4}{|l|}{ Storage days } \\
\hline & 0 & 5 & 10 & 15 \\
\hline Control & $66.71 \pm 0.38 \mathrm{eA}$ & $62.14 \pm 0.30 \mathrm{eB}$ & $58.41 \pm 1.28 \mathrm{eC}$ & $52.13 \pm 0.56 \mathrm{eD}$ \\
\hline CPH $2 \%$ & $71.16 \pm 0.28 \mathrm{dA}$ & $65.19 \pm 0.18 \mathrm{~dB}$ & $61.51 \pm 1.31 \mathrm{dC}$ & $57.71 \pm 0.43 \mathrm{dD}$ \\
\hline $\mathrm{CPH} 4 \%$ & $76.74 \pm 0.31 \mathrm{cA}$ & $69.99 \pm 1.50 \mathrm{cB}$ & $64.09 \pm 1.16 \mathrm{cC}$ & $60.09 \pm 0.23 \mathrm{cD}$ \\
\hline СРH 6\% & $81.61 \pm 0.28 \mathrm{bA}$ & $73.32 \pm 1.21 \mathrm{bB}$ & $69.19 \pm 1.23 \mathrm{bC}$ & $65.16 \pm 0.17 \mathrm{bD}$ \\
\hline CPH $8 \%$ & $85.98 \pm 0.44 \mathrm{aA}$ & $79.18 \pm 0.50 \mathrm{aB}$ & $75.34 \pm 0.51 \mathrm{aC}$ & $70.01 \pm 0.33 \mathrm{aD}$ \\
\hline
\end{tabular}

Table 2. $\mathrm{DPPH}$ of casein protein hydrolysate $(\mathrm{CPH})$ powder incorporated beef nuggets during storage. $\mathrm{CPH}$ : casein protein hydrolysate. All the values are means of triplicate determinations \pm Standard Deviation (SD). Means within the column with different small letters are significantly different $(\mathrm{p}<0.05)$ and different capital letters within the row differed significantly.

\begin{tabular}{|l|l|l|l|l|}
\hline \multirow{2}{*}{ Groups } & \multicolumn{4}{l}{ TVBN $(\mathbf{m g} / \mathbf{1 0 0 0} \mathbf{g})$} \\
\cline { 2 - 5 } & \multicolumn{2}{|l|}{ Storage days } & $\mathbf{1 0}$ & $\mathbf{1 5}$ \\
\cline { 2 - 5 } & $\mathbf{0}$ & $18.45 \pm 0.15 \mathrm{aC}$ & $26.05 \pm 1.02 \mathrm{aB}$ & $30.05 \pm 2.50 \mathrm{aA}$ \\
\hline Control & $10.37 \pm 1.53 \mathrm{aD}$ & $16.53 \pm 0.33 \mathrm{bC}$ & $22.64 \pm 0.41 \mathrm{bB}$ & $27.05 \pm 1.04 \mathrm{bA}$ \\
\hline CPH2\% & $7.87 \pm 2.07 \mathrm{bD}$ & $12.33 \pm 0.77 \mathrm{cC}$ & $20.87 \pm 1.22 \mathrm{cB}$ & $24.45 \pm 0.25 \mathrm{cA}$ \\
\hline CPH4\% & $6.37 \pm 2.00 \mathrm{cD}$ & $11.53 \pm 0.82 \mathrm{dC}$ & $16.65 \pm 0.35 \mathrm{~dB}$ & $21.99 \pm 0.33 \mathrm{dA}$ \\
\hline CPH6\% & $5.12 \pm 2.06 \mathrm{dD}$ & $10.47 \pm 0.71 \mathrm{eC}$ & $14.25 \pm 0.51 \mathrm{eB}$ & $19.26 \pm 0.28 \mathrm{eA}$ \\
\hline CPH8\% & $5.00 \pm 2.08 \mathrm{dD}$ & &
\end{tabular}

Table 3. TVBN of casein protein hydrolysate $(\mathrm{CPH})$ incorporated beef nuggets during storage. $\mathrm{CPH}$ : casein protein hydrolysate. All the values are means of triplicate determinations \pm Standard Deviation (SD). Means within the column with different small letters are significantly different $(\mathrm{p}<0.05)$ and different capital letters within the row differed significantly.

DPPH free radical scavenging assay. In this study, the DPPH scavenging assay was conducted as the first and foremost measure to determine the anti-oxidant activity of casein protein hydrolysates (CPH) powder present in beef nuggets. The incorporation of casein protein hydrolysate $(\mathrm{CPH})$ powder in the raw beef nuggets caused a significant increased $(\mathrm{p}<0.05)$ in the free-radical scavenging activity $(\mathrm{DPPH})$ of the beef nuggets (Table 2). The results showed that the highest DPPH value was observed in the group that was incorporated with $8 \% \mathrm{CPH}$ powder at the beginning of the storage period while the lowest value was shown by the control. The DPPH free radical scavenging activity increased significantly $(\mathrm{p}<0.05)$ within groups, in all the samples with the increase in storage time. At the end of the storage period, the highest DPPH value was observed in the treatment group having 8\% CPH powder whilst the lowest DPPH value was shown by the control at the end of the storage period. The results of the present study are in accordance with the findings of ${ }^{28}$, who also reported significantly higher DPPH radical scavenging activity of the pork sausages enriched with synthetic anti-oxidants and mechanically deboned chicken meat hydrolysates. Similar results were also reported by ${ }^{29}$ for the flesh hydrolysates of tannery. In addition ${ }^{30,31}$ also showed by their results that the casein calcium peptides (CCP's) are free-radical scavengers, especially of the peroxyl radical which is the chief propagator of the oxidation chain reaction of fats, thus ending the chain reaction. The anti-oxidant activity of meat has also been related to the casein-derived peptides the human milk $^{32}$.

Total volatile basic nitrogen (TVBN). The TVBN of beef nuggets incorporated with CPH powder showed significant variation with respect to treatment and storage intervals. The results thus acquired showed that the highest value of TVBN was observed in the control group ( $\mathrm{CPH} \%$ ) at the beginning of the storage period while the lowest value was shown by $\mathrm{CPH} 8 \%$ (Table 3). The TVBN value decreased significantly $(\mathrm{p}<0.05)$ within groups, in all the samples with the increase in storage time. At the end of storage period (at day 15), the highest TVBN value was observed in the beef nuggets that were made without the incorporation of casein protein hydrolysate $(\mathrm{CPH})$ powder which was the control group $(\mathrm{CPH} 0 \%)$, followed by $\mathrm{CPH} 2 \%$ whilst the lowest TVBN value was observed in the group incorporated with $8 \% \mathrm{CPH}$ powder, at the end of the storage period. The results of present study are in agreement with the findings of ${ }^{33}$, who stated that after storage intervals, the TVBN contents of the additives containing soybean protein hydrolysate were lower as compared to the control samples but were not significantly different. Similar observations were reported by Al. Bachir and Mehiob, who found the same effect of TVBN with the irradiated buffalo meat. Abu Saleem and Banaru ${ }^{34}$ also demonstrated that soy protein coating effectively retarded lipid oxidation in pre-cooked beef patties.

Peroxide value (POV). Peroxide value of beef nuggets with $\mathrm{CPH}$ powder depicted significant difference with respect to treatment and storage. The results showed that the highest value of per-oxidation was observed in 


\begin{tabular}{|l|l|l|l|l|}
\hline \multirow{4}{*}{ Groups } & \multicolumn{4}{|l|}{ POV (meq peroxides $/ \mathbf{k g}$ ) } \\
\cline { 2 - 5 } & Storage days & $\mathbf{5}$ & 10 & 15 \\
\cline { 2 - 5 } & $\mathbf{0}$ & $0.68 \pm 0.08 \mathrm{aC}$ & $0.74 \pm 0.02 \mathrm{aB}$ & $0.80 \pm 0.04 \mathrm{aA}$ \\
\hline Control & $0.64 \pm 0.05 \mathrm{aD}$ & $0.65 \pm 0.05 \mathrm{bC}$ & $0.72 \pm 0.12 \mathrm{bB}$ & $0.78 \pm 0.03 \mathrm{bA}$ \\
\hline CPH $\%$ & $0.62 \pm 0.04 \mathrm{bD}$ & $0.65 \pm 0.04 \mathrm{bC}$ & $0.73 \pm 0.22 \mathrm{bB}$ & $0.76 \pm 0.03 \mathrm{cA}$ \\
\hline CPH $4 \%$ & $0.58 \pm 0.02 \mathrm{cD}$ & $0.63 \pm 0.03 \mathrm{cC}$ & $0.70 \pm 0.15 \mathrm{cB}$ & $0.74 \pm 0.02 \mathrm{dA}$ \\
\hline CPH $6 \%$ & $0.54 \pm 0.06 \mathrm{dD}$ & $0.60 \pm 0.02 \mathrm{dC}$ & $0.68 \pm 0.06 \mathrm{~dB}$ & $0.70 \pm 0.01 \mathrm{eA}$ \\
\hline CPH $8 \%$ & $0.55 \pm 0.03 \mathrm{dD}$ & & & \\
\hline
\end{tabular}

Table 4. POV of casein protein hydrolysate $(\mathrm{CPH})$ incorporated beef nuggets during storage. $\mathrm{CPH}$ : casein protein hydrolysate. All the values are means of triplicate determinations \pm Standard Deviation (SD). Means within the column with different small letters are significantly different $(\mathrm{p}<0.05)$ and different capital letters within the row differed significantly.

\begin{tabular}{|c|c|c|c|c|}
\hline \multirow[b]{3}{*}{ Groups } & \multicolumn{4}{|c|}{ TBARS (MDA/kg) } \\
\hline & \multicolumn{4}{|l|}{ Storage days } \\
\hline & 0 & 5 & 10 & 15 \\
\hline Control & $0.43 \pm 0.03 \mathrm{aD}$ & $0.46 \pm 0.04 \mathrm{aC}$ & $0.50 \pm 0.05 \mathrm{aB}$ & $0.53 \pm 0.04 \mathrm{aA}$ \\
\hline $\mathrm{CPH} 2 \%$ & $0.39 \pm 0.04 \mathrm{bD}$ & $0.42 \pm 0.03 \mathrm{bC}$ & $0.46 \pm 0.04 \mathrm{bB}$ & $0.49 \pm 0.05 \mathrm{bA}$ \\
\hline СРH $4 \%$ & $0.38 \pm 0.04 \mathrm{bD}$ & $0.42 \pm 0.03 \mathrm{bC}$ & $0.43 \pm 0.02 \mathrm{cB}$ & $0.45 \pm 0.03 \mathrm{cA}$ \\
\hline CPH6\% & $0.34 \pm 0.03 \mathrm{cD}$ & $0.41 \pm 0.03 \mathrm{cC}$ & $0.43 \pm 0.02 \mathrm{cB}$ & $0.46 \pm 0.03 \mathrm{cA}$ \\
\hline СРH8\% & $0.30 \pm 0.01 \mathrm{dD}$ & $0.36 \pm 0.02 \mathrm{dC}$ & $0.39 \pm 0.03 \mathrm{~dB}$ & $0.43 \pm 0.02 \mathrm{dA}$ \\
\hline
\end{tabular}

Table 5. TBARS of casein protein hydrolysate $(\mathrm{CPH})$ powder incorporated beef nuggets during storage. $\mathrm{CPH}$ : casein protein hydrolysate. All the values are means of triplicate determinations \pm Standard Deviation (SD). Means within the column with different small letters are significantly different $(\mathrm{p}<0.05)$ and different capital letters within the row differed significantly.

the control group at the beginning of the storage period while the lowest value was shown by CPH 8\% (Table 4). The POV increased significantly $(\mathrm{p}<0.05)$ in all the samples with the increase in storage time. At the end of the storage period (day 15), the highest POV was observed in the beef nuggets that were made without the incorporation of casein protein hydrolysate $(\mathrm{CPH})$ powder i.e. control whilst the lowest POV was shown by $\mathrm{CPH} 8 \%$ which significantly indicates the strong anti-oxidant and anti-microbial potential of casein protein hydrolysates, in plummeting the lipid oxidation which is evident from the previous experimental reports of ${ }^{16}$. The results of our study are in agreement with the findings of ${ }^{35}$ who reported that decreased in the peroxide value (POV) in the grass carp mince during storage, with the incorporation of grass carp protein hydrolysates and cracklings hydrolysates in the pork meat balls as reported by ${ }^{36}$. The significantly strong suppression of the lipid oxidation reaction, in both POV and TBARS, by the incorporation of hydrolysed potato protein in the cooked beef patties was reported in another study conducted by ${ }^{12,37}$.

Thio-barbituric acid reactive substances (TBARS). The TBARS value of beef nuggets depicted significant variation between treatments and storage intervals. However, the raw beef nuggets that were made by the incorporation $8 \%$ casein protein hydrolysate $(\mathrm{CPH})$ powder, maintained significantly lower level of TBARS at the end of storage in contrast with the levels of the control (CPH $0 \%)$. The results thus obtained depicted highest TBARS value in control sample at the start of the storage period while the lowest value was shown by the beef nuggets that were incorporated with $8 \%$ casein protein hydrolysate powder (Table 5 ). The TBARS value increased significantly $(\mathrm{p}<0.05)$ in all the samples during storage. At the end of storage period, the highest value of TBARS was observed in the nuggets that were not incorporated with the peptide powder i.e. the control group (CPH $0 \%$ ) with the value $0.53 \pm 0.04 \mathrm{MDA} / \mathrm{kg}$, followed by $\mathrm{CPH} 2 \%$ while the lowest value of the TBARS assay was shown by $\mathrm{CPH} 8 \%$, at the end of the storage period. The maintenance of lower TBARS values in the $\mathrm{CPH}$ powder incorporated treatments might be due to the presence of potent anti-oxidant activity of the casein protein hydrolysates. The results obtained are in accordance with the previous experimental reports of ${ }^{38}$. The results of the present research are also supported by the results of ${ }^{16}$ in the ground beef and mechanically deboned poultry meat incorporation with casein protein hydrolysate $(\mathrm{CPH})$. Abu Saleem and Banaru ${ }^{34}$ also demonstrated that soy protein coating effectively retarded lipid oxidation in pre-cooked beef patties. Earlier research also reported that MDA concentrations higher than $0.5 \mathrm{mg} / \mathrm{kg}$ are the threshold value for the perception of rancidity by consumers ${ }^{39}$. These results are also in agreement with the results reported by ${ }^{40}$, for other anti-oxidants applied to the meatballs.

Physico-chemical tests. $\quad p H$. The $\mathrm{pH}$ of the raw beef nuggets incorporated with different concentrations of casein protein hydrolysate $(\mathrm{CPH})$ powder didn't vary significantly, at the beginning of the storage period (on 


\begin{tabular}{|c|c|c|c|c|}
\hline \multirow[b]{3}{*}{ Groups } & \multicolumn{4}{|l|}{$\mathrm{pH}$} \\
\hline & \multicolumn{4}{|l|}{ Storage days } \\
\hline & 0 & 5 & 10 & 15 \\
\hline Control & $5.70 \pm 0.07 \mathrm{dD}$ & $6.23 \pm 0.08 \mathrm{aC}$ & $6.41 \pm 0.02 \mathrm{aB}$ & $6.71 \pm 0.05 \mathrm{aA}$ \\
\hline $\mathrm{CPH} 2 \%$ & $5.81 \pm 0.03 \mathrm{cD}$ & $6.15 \pm 0.17 \mathrm{bC}$ & $6.24 \pm 0.21 \mathrm{bB}$ & $6.54 \pm 0.01 \mathrm{bA}$ \\
\hline $\mathrm{CPH} 4 \%$ & $5.79 \pm 0.04 \mathrm{cD}$ & $6.01 \pm 0.20 \mathrm{cC}$ & $6.13 \pm 0.32 \mathrm{cB}$ & $6.23 \pm 0.12 \mathrm{cA}$ \\
\hline $\mathrm{CPH} 6 \%$ & $5.84 \pm 0.08 \mathrm{bC}$ & $5.85 \pm 0.16 \mathrm{dC}$ & $5.97 \pm 0.16 \mathrm{~dB}$ & $6.09 \pm 0.19 \mathrm{dA}$ \\
\hline CPH8\% & $5.91 \pm 0.06 \mathrm{aB}$ & $5.71 \pm 0.11 \mathrm{eD}$ & $5.81 \pm 0.12 \mathrm{eC}$ & $5.94 \pm 0.19 \mathrm{eA}$ \\
\hline
\end{tabular}

Table 6. $\mathrm{pH}$ of casein protein hydrolysate $(\mathrm{CPH})$ powder incorporated raw beef nuggets. $\mathrm{CPH}$ : casein protein hydrolysate. All the values are means of triplicate determinations \pm Standard Deviation (SD). Means within the column with different small letters are significantly different $(\mathrm{p}<0.05)$ and different capital letters within the row differed significantly.

day 0 ) but it varied significantly $(\mathrm{p}<0.05)$ on the 5 th day of storage (Table 6$)$. The results thus obtained showed that the highest $\mathrm{pH}$ value was recorded for the treatment group that was incorporated with $8 \%$ casein protein hydrolysate $(\mathrm{CPH})$ powder, at the beginning of the storage period followed by $\mathrm{CPH} 6 \%$ while the lowest $\mathrm{pH}$ value was shown by the control group (CPH $0 \%)$. The value of $\mathrm{pH}$ increased significantly $(\mathrm{p}<0.05)$ within groups except for $\mathrm{CPH} 8 \%$, with advancement in storage duration but this increase in the $\mathrm{pH}$ value of $\mathrm{CPH}$ powder incorporated beef nuggets was significantly lower than the control group. At the end of the storage period, the highest $\mathrm{pH}$ was observed in the control group, followed by $\mathrm{CPH} 2 \%$ whereas the lowest value of $\mathrm{pH}$ was observed in the group having $8 \% \mathrm{CPH}$ powder.

The $\mathrm{pH}$ of casein protein hydrolysate $(\mathrm{CPH})$ powder incorporated treatment groups as well as control followed an increasing trend throughout the storage period except for $\mathrm{CPH} 8 \%$ on day 5 , but the rate of the increase in $\mathrm{pH}$ of casein protein hydrolysate $(\mathrm{CPH})$ powder incorporated treatments was lower than that of the control group. Thus, the $\mathrm{pH}$ recorded in the present study is completely in the range as reported by ${ }^{41}$ in ground chevon (lamb meat) during the refrigerated storage $\left(4 \pm 1^{\circ} \mathrm{C}\right)$. Sharma et al..$^{28}$ also stated the increase in $\mathrm{pH}$ of pork sausages that were incorporated with mechanically deboned chicken meat hydrolysates (MDCM). They also reported a dose-dependent, lower rate of $\mathrm{pH}$ increment in the MDCM hydrolysate incorporated products.

Color. Color is one of the principal and strong physical parameter for determining the extent of spoilage in the meat. The incorporation of the peptide powder at different concentrations may influence the color profile due to its contact with the other food components and with the passage of time it also changes because of lipid oxidation and microbial growth in the meat and meat products. Hence, the instrumental color profile analysis turns out to be an important entity for studying the change in color profile during the period of storage. Objective meat color is generally measured in the CIE $\mathrm{L}^{*} \mathrm{a}^{\star} \mathrm{b}^{\star}$ color $\operatorname{space}^{24,42}$.

The results thus obtained showed that the value of lightness decreased significantly $(\mathrm{p}<0.05)$ among groups along the storage duration. The higher value of lightness was observed at the beginning of the storage period (at day 0 ) in the beef nuggets that were incorporated with $8 \%$ casein protein hydrolysate $(\mathrm{CPH})$ powder while slightly lower value was shown by the control group ( $\mathrm{CPH} 0 \%$ ) (Table 7). The value of lightness decreased significantly in all the samples with the increase in storage time. In contrast to lightness, the redness or $\mathrm{a}^{*}$ value increased significantly $(\mathrm{p}<0.05)$ in all the treatment groups, the higher value of redness was observed in the control group $(\mathrm{CPH} 0 \%)$ while lower value was observed in the group containing $8 \%$ casein protein hydrolysate powder. As far as the yellowness or $b^{*}$ value is concerned, a significant decrease was observed in the yellowness of control with the increase in the storage time. Higher value of yellowness was shown by the control group (CPH $0 \%)$ whereas a lower value was observed in the group that was incorporated with $8 \%$ casein protein hydrolysate $(\mathrm{CPH})$ powder at the start of storage period (at day 0 ). At the end of the storage period, the highest value of lightness was observed in the beef nuggets made without the incorporation of $\mathrm{CPH}$ powder whilst the lowest value of lightness was shown by CPH $8 \%$, in contrast to lightness the redness followed a decreasing trend at the end of storage period (at day 15), the highest $\mathrm{a}^{*}$ value was shown by $\mathrm{CPH} 8 \%$ whereas the lowest value was shown by the control group (CPH $0 \%)$. Similarly, the yellowness or $\mathrm{b}^{*}$ value of casein protein hydrolysate $(\mathrm{CPH})$ powder incorporated beef nuggets followed a decreasing trend. At the end of the storage period (at day 15), the highest $b^{*}$ value was observed in the group that was incorporated with $8 \%$ casein protein hydrolysate $(\mathrm{CPH})$ powder whilst the lowest $b^{*}$ value was shown by the control group ( $\left.\mathrm{CPH} 0 \%\right)$. This indicated that even though, the $\mathrm{CPH}$ powder incorporated beef nuggets had to some extent, lower $b^{\star}$ value on the initial days but it was retained during the course of time and this might be due to the added anti-oxidant properties of casein protein hydrolysate powder. The results of the present study are in accordance with the findings of ${ }^{43}$ who also reported that the meat emulsions that were incorporated with hydrolyzed potato protein (HPP) were darker (i.e. lower value of $\mathrm{L}^{*}$ ) as compared to those made without the incorporation of HPP. Similar results, where the yellowness $\left(b^{*}\right)$ of meat emulsions incorporated with hydrolyzed potato protein had lower values than those made without HPP were reported as stated earlier by ${ }^{43}$ are in agreement with the results of our study.

In case of redness $\left(\mathrm{a}^{*}\right.$ value), the results of our research were in accordance with the results of ${ }^{44}$ who also reported loss of redness values in the red muscle due to oxidation. 


\begin{tabular}{|c|c|c|c|c|}
\hline \multirow[b]{3}{*}{ Groups } & \multicolumn{4}{|l|}{ Color } \\
\hline & \multicolumn{4}{|l|}{ Storage days } \\
\hline & 0 & 5 & 10 & 15 \\
\hline & \multicolumn{4}{|l|}{$L^{*}$ (lightness) } \\
\hline Control & $50.00 \pm 0.99 \mathrm{dA}$ & $48.03 \pm 1.15 \mathrm{cB}$ & $46.05 \pm 1.46 \mathrm{aC}$ & $44.29 \pm 1.09 \mathrm{aD}$ \\
\hline $\mathrm{CPH} 2 \%$ & $50.09 \pm 1.39 \mathrm{dA}$ & $48.00 \pm 0.98 \mathrm{cB}$ & $45.73 \pm 1.05 \mathrm{cC}$ & $43.90 \pm 1.75 b D$ \\
\hline $\mathrm{CPH} 4 \%$ & $50.17 \pm 1.37 \mathrm{cA}$ & $48.02 \pm 1.11 \mathrm{cB}$ & $45.83 \pm 0.91 \mathrm{bC}$ & $43.79 \pm 1.60 \mathrm{bD}$ \\
\hline $\mathrm{CPH} 6 \%$ & $50.37 \pm 1.43 \mathrm{bA}$ & $48.24 \pm 1.17 \mathrm{bB}$ & $45.86 \pm 0.92 \mathrm{bC}$ & $42.54 \pm 1.91 \mathrm{cD}$ \\
\hline \multirow[t]{2}{*}{ CPH 8\% } & $50.42 \pm 1.52 \mathrm{aA}$ & $48.35 \pm 1.95 \mathrm{aB}$ & $45.89 \pm 1.18 \mathrm{bC}$ & $42.24 \pm 1.49 \mathrm{dD}$ \\
\hline & \multicolumn{4}{|l|}{$a^{*}$ (redness) } \\
\hline Control & $7.44 \pm 0.45 \mathrm{cA}$ & $7.22 \pm 0.31 \mathrm{~dB}$ & $6.17 \pm 0.61 \mathrm{eC}$ & $5.55 \pm 0.15 \mathrm{eD}$ \\
\hline CPH $2 \%$ & $7.40 \pm 0.22 \mathrm{dA}$ & $7.35 \pm 0.77 \mathrm{cA}$ & $6.26 \pm 0.32 \mathrm{~dB}$ & $5.60 \pm 0.35 \mathrm{dC}$ \\
\hline $\mathrm{CPH} 4 \%$ & $7.53 \pm 0.33 \mathrm{bA}$ & $7.36 \pm 0.77 \mathrm{cB}$ & $6.35 \pm 0.41 c \mathrm{c}$ & $5.65 \pm 0.34 \mathrm{cD}$ \\
\hline СРH 6\% & $7.56 \pm 0.36 \mathrm{bA}$ & $7.42 \pm 0.11 \mathrm{bB}$ & $6.45 \pm 0.22 \mathrm{bC}$ & $5.75 \pm 0.55 \mathrm{bD}$ \\
\hline \multirow[t]{2}{*}{ CPH 8\% } & $7.60 \pm 0.38 \mathrm{aA}$ & $7.51 \pm 0.33 \mathrm{aB}$ & $6.65 \pm 0.30 \mathrm{aC}$ & $5.80 \pm 0.50 \mathrm{aD}$ \\
\hline & \multicolumn{4}{|l|}{$\mathbf{b}^{*}$ (yellowness) } \\
\hline Control & $12.99 \pm 0.52 \mathrm{aA}$ & $12.00 \pm 0.15 \mathrm{dA}$ & $10.18 \pm 0.10 \mathrm{cB}$ & $9.60 \pm 0.19 \mathrm{dC}$ \\
\hline $\mathrm{CPH} 2 \%$ & $12.97 \pm 0.55 \mathrm{aA}$ & $12.05 \pm 0.16 \mathrm{cB}$ & $11.17 \pm 0.11 \mathrm{cC}$ & $10.06 \pm 0.39 \mathrm{cD}$ \\
\hline $\mathrm{CPH} 4 \%$ & $12.92 \pm 0.43 \mathrm{bA}$ & $12.09 \pm 0.17 \mathrm{bB}$ & $11.26 \pm 0.20 \mathrm{bC}$ & $10.17 \pm 0.64 \mathrm{bD}$ \\
\hline СРH 6\% & $12.64 \pm 0.61 \mathrm{cA}$ & $12.11 \pm 0.55 \mathrm{bB}$ & $11.31 \pm 0.23 \mathrm{bC}$ & $10.25 \pm 0.55 \mathrm{aD}$ \\
\hline СРH 8\% & $12.62 \pm 0.60 \mathrm{cA}$ & $12.17 \pm 0.52 \mathrm{aB}$ & $11.41 \pm 0.30 \mathrm{aC}$ & $10.35 \pm 0.45 \mathrm{aD}$ \\
\hline
\end{tabular}

Table 7. Color of casein protein hydrolysate $(\mathrm{CPH})$ powder incorporated raw beef nuggets. $\mathrm{CPH}$ : casein protein hydrolysate. All the values are means of triplicate determinations \pm Standard Deviation (SD). Means within the column with different small letters are significantly different $(\mathrm{p}<0.05)$ and different capital letters within the row differed significantly.

\begin{tabular}{|l|l|l|l|l|}
\hline \multirow{5}{*}{ Groups } & \multicolumn{5}{l}{ Total coliforms count $(\log 10$ CFU/g) } \\
\cline { 2 - 5 } & Storage days & $\mathbf{5}$ & $\mathbf{1 0}$ & $\mathbf{1 5}$ \\
\cline { 2 - 5 } & $\mathbf{0}$ & $8.68 \pm 2.30 \mathrm{aC}$ & $9.17 \pm 0.50 \mathrm{aB}$ & $10.27 \pm 2.09 \mathrm{aA}$ \\
\hline Control & $8.01 \pm 1.00 \mathrm{aD}$ & $8.00 \pm 1.99 \mathrm{bC}$ & $8.67 \pm 1.04 \mathrm{bB}$ & $9.12 \pm 2.10 \mathrm{bA}$ \\
\hline CPH $\%$ & $7.88 \pm 1.28 \mathrm{bD}$ & $7.94 \pm 1.50 \mathrm{cC}$ & $8.47 \pm 1.25 \mathrm{cB}$ & $8.89 \pm 2.07 \mathrm{cA}$ \\
\hline CPH $\%$ & $7.44 \pm 1.45 \mathrm{cD}$ & $6.90 \pm 1.09 \mathrm{dC}$ & $7.77 \pm 2.03 \mathrm{~dB}$ & $8.17 \pm 2.35 \mathrm{dA}$ \\
\hline CPH $\%$ & $6.65 \pm 1.12 \mathrm{dD}$ & $6.29 \pm 1.29 \mathrm{eC}$ & $7.27 \pm 1.47 \mathrm{eB}$ & $7.97 \pm 2.50 \mathrm{eA}$ \\
\hline CPH $\%$ & $5.59 \pm 1.25 \mathrm{eD}$ & & & \\
\hline
\end{tabular}

Table 8. Total coliforms count (TCC) of casein protein hydrolysate $(\mathrm{CPH})$ powder incorporated raw beef nuggets. CPH: casein protein hydrolysate. All the values are means of triplicate determinations \pm Standard Deviation (SD). Means within the column with different small letters are significantly different $(\mathrm{p}<0.05)$ and different capital letters within the row differed significantly.

Microbial analysis. Total coliforms count (TCC). The total coliform count analysis was carried out in order to determine the microbial count of pathogenic flora. The results acquired showed that the highest coliform count was found in the control group ( $\mathrm{CPH} 0 \%)$, at the beginning of the storage period while the lowest coliform count was found in the treatment group that was incorporated with $8 \%$ of casein protein hydrolysate $(\mathrm{CPH})$ powder (Table 8$)$. The total coliforms count decreased significantly $(\mathrm{p}<0.05)$ within groups up to day 5 except the control group but this decrease in the coliform counts of the $\mathrm{CPH}$ powder incorporated beef nuggets was significantly higher at day 5 . At the end of the storage period, the highest coliform count was observed in the control group, followed by $\mathrm{CPH} 2 \%$ whereas the lowest coliform count was found in the treatment group incorporated with $8 \% \mathrm{CPH}$ powder.

It became clear from the results of the present study that the total coliform counts (TCC) decreased significantly $(\mathrm{p}<0.05)$ at day 5 in all the treatment groups incorporated with $\mathrm{CPH}$ powder but the difference was more obvious in the last two treatment groups (CPH $8 \%$ and $\mathrm{CPH} 6 \%$ ), having higher concentration of $\mathrm{CPH}$ powder. After that, a significant increase in the total coliform count was seen in all the treatment groups as well as the control group. However, the casein protein hydrolysate $(\mathrm{CPH})$ powder incorporated treatment groups showed significantly lower counts of coliforms, at the end of the storage period. The results of the present study are comparable with the results reported by ${ }^{45}$ in hot deboned pork incorporated with lactoferrin and casein peptides. Umuhumuza et al. ${ }^{46}$ also studied the supplementation of various hydrolyzed proteins isolated from skimmed 


\begin{tabular}{|c|c|c|c|c|}
\hline \multirow[b]{3}{*}{ Groups } & \multicolumn{4}{|c|}{ Total aerobic bacteria $(\log 10 \mathrm{CFU} / \mathrm{g})$} \\
\hline & \multicolumn{4}{|l|}{ Storage days } \\
\hline & 0 & 5 & 10 & 15 \\
\hline Control & $8.35 \pm 0.10 \mathrm{aD}$ & $9.24 \pm 0.30 \mathrm{aC}$ & $10.22 \pm 0.02 \mathrm{aB}$ & $10.94 \pm 0.24 \mathrm{aA}$ \\
\hline CPH $2 \%$ & $6.89 \pm 0.29 \mathrm{bD}$ & $7.37 \pm 0.47 \mathrm{bC}$ & $8.36 \pm 0.22 \mathrm{bB}$ & $8.96 \pm 0.36 \mathrm{bA}$ \\
\hline $\mathrm{CPH} 4 \%$ & $5.50 \pm 0.32 \mathrm{cD}$ & $6.37 \pm 0.37 \mathrm{cC}$ & $6.94 \pm 0.12 \mathrm{cB}$ & $7.27 \pm 0.28 \mathrm{cA}$ \\
\hline $\mathrm{CPH} 6 \%$ & $4.25 \pm 0.20 \mathrm{dD}$ & $5.42 \pm 0.24 \mathrm{dC}$ & $6.37 \pm 0.19 \mathrm{cB}$ & $7.17 \pm 0.22 \mathrm{cA}$ \\
\hline CPH $8 \%$ & $3.30 \pm 0.30 \mathrm{eD}$ & $4.83 \pm 0.28 \mathrm{eC}$ & $5.25 \pm 0.36 \mathrm{~dB}$ & $6.35 \pm 0.19 \mathrm{dA}$ \\
\hline
\end{tabular}

Table 9. Total aerobic bacteria $(\mathrm{TAB})$ of casein protein hydrolysate $(\mathrm{CPH})$ powder incorporated raw beef nuggets. $\mathrm{CPH}$ : casein protein hydrolysate. All the values are means of triplicate determinations \pm Standard Deviation (SD). Means within the column with different small letters are significantly different $(\mathrm{p}<0.05)$ and different capital letters within the row differed significantly.

\begin{tabular}{|c|c|c|c|c|c|c|c|c|c|c|c|}
\hline & TPC & DPPH & TVBN & POV & TBARS & pH & Coliform & TAB & L & a & b \\
\hline TPC & 1 & & & & & & & & & & \\
\hline DPPH & 0.73892 & 1 & & & & & & & & & \\
\hline TVBN & -0.49173 & -0.90853 & 1 & & & & & & & & \\
\hline POV & -0.47019 & -0.90364 & 0.970214 & 1 & & & & & & & \\
\hline TBARS & -0.6828 & -0.96862 & 0.909496 & 0.908614 & 1 & & & & & & \\
\hline $\mathrm{pH}$ & -0.59344 & -0.83715 & 0.877013 & 0.796139 & \begin{tabular}{|l|l|}
0.806188 \\
\end{tabular} & 1 & & & & & \\
\hline Coliform & -0.76498 & -0.97218 & 0.866643 & 0.872296 & 0.949872 & \begin{tabular}{|l|l|}
0.823002 \\
\end{tabular} & 1 & & & & \\
\hline TAB & -0.87701 & -0.94473 & \begin{tabular}{|l}
0.797051 \\
\end{tabular} & \begin{tabular}{|l|}
0.772508 \\
\end{tabular} & \begin{tabular}{|l|}
0.934322 \\
\end{tabular} & \begin{tabular}{|l}
0.781914 \\
\end{tabular} & 0.935578 & 1 & & & \\
\hline $\mathrm{L}$ & \begin{tabular}{|l|}
0.067774 \\
\end{tabular} & 0.621435 & -0.84055 & -0.86081 & -0.67481 & -0.57837 & -0.59459 & -0.43504 & 1 & & \\
\hline $\mathrm{a}$ & \begin{tabular}{|l|}
0.281671 \\
\end{tabular} & \begin{tabular}{|l|l|}
0.722301 \\
\end{tabular} & -0.8983 & -0.91552 & -0.74766 & -0.71206 & -0.72127 & -0.56492 & \begin{tabular}{|l|}
0.942769 \\
\end{tabular} & 1 & \\
\hline $\mathrm{b}$ & 0.24558 & 0.715502 & -0.9258 & -0.90052 & -0.76067 & -0.77703 & -0.69488 & -0.57285 & 0.932685 & 0.960029 & 1 \\
\hline
\end{tabular}

Table 10. Correlation study for $\mathrm{CPH}$ treated beef nuggets among different parameters.

milk and their effects on the growth of probiotic bacteria and established that the fraction and type of protein which is used directly, affects the rate and growth of micro-organisms.

Total aerobic bacteria (TAB). The microbial counts, in the casein protein hydrolysate (CPH) powder incorporated treatment groups and control group were analyzed for the estimation of Total Aerobic Bacteria (TAB). The results showed that the highest $\mathrm{TAB}$ count was found in control at the beginning of the storage period while the lowest TAB count was found in the treatment group that was incorporated with $8 \%$ casein protein hydrolysate $(\mathrm{CPH})$ powder (Table 9$)$. The TAB count increased significantly $(\mathrm{p}<0.05)$ within groups until day 15 , except on day 0 but this increase in the Total Aerobic Bacteria counts of the $\mathrm{CPH}$ powder incorporated beef nuggets was significantly lower throughout the storage period. At the end of the storage period, the highest TAB count was observed in the control group (CPH $0 \%$ ), followed by $\mathrm{CPH} 2 \%$ whilst the lowest TAB count was found in the treatment group that was incorporated with $8 \% \mathrm{CPH}$ powder. The results thus obtained indicated an elevated count of the TAB and in the control group $(\mathrm{CPH} 0 \%)$ on the 15 th day of refrigeration storage while a lower TAB count was observed in the group that was incorporated with $\mathrm{CPH} 8 \%$.

It became clear from the results of our study that with the increase in concentration of the CPH powder, the microbial population of the aerobic bacteria decreased significantly in groups and these results also showed that a higher concentration of $\mathrm{CPH}$ powder incorporated in beef nuggets, retards the growth of the Total Aerobic Bacteria (TAB). The results of our study are in accordance with the results of ${ }^{47}$, which indicated that the higher anti-oxidant and anti-microbial activity of the whole hydolysates may be due to the presence of the peptides of different sizes and charges which contribute to the overall activity of the protein hydrolysates.

Correlation and stepwise regression study. The correlation and stepwise regression study for beef nuggets is shown in Tables 10 and 11. Correlation study showed that Total phenolic content was significant positive associated with DPPH activity of beef nuggets and negatively associated with TBARS value, total coliform and total bacterial count. However, TVBN, POV pH and color values were found non-significant correlation. However, DPPH activity of CPH treated meat had highly significant negative association with TVBN, POV, TBARS, pH, Coliform and Total Bacterial Counts whereas, color value of stored meat showed positive association with DPPH activity. TVBN value showed the highly positive correlation with POV, TBARS, pH, Coliform, TBC of treated meat with $\mathrm{CPH}$ powder whereas, color value showed negative association with TVBN value. Similarly, POV value significantly increased as the TBARS, $\mathrm{pH}$ of meat was increased with the storage along with bacteria load (total coliform and total bacterial count). Whereas, color value showed deterioration with the increased of POV values. Likewise, TBARS value of $\mathrm{CPH}$ treated meat during storage showed the positive association with $\mathrm{pH}$ 


\begin{tabular}{|l|c|l|c|l|c|c|c|c|}
\hline Intercept & Coefficients & Standard error & $\mathbf{t}$ stat & $\mathbf{p}$-value & Lower 95\% & Upper 95\% & Lower 95.0\% & Upper 95.0\% \\
\hline & 0.686201 & 0.195198 & 3.515418 & 0.003429 & 0.267544 & 1.104859 & 0.267544 & 1.104859 \\
\hline TPC & 0.002076 & 0.000516 & 4.024818 & 0.001254 & 0.00097 & 0.003182 & 0.00097 & 0.003182 \\
\hline DPPH & -0.00438 & 0.001236 & -3.54416 & 0.003238 & -0.00703 & -0.00173 & -0.00703 & -0.00173 \\
\hline TVBN & -0.00538 & 0.001922 & -2.80076 & 0.014159 & -0.0095 & -0.00126 & -0.0095 & -0.00126 \\
\hline TAB & 0.026322 & 0.005136 & 5.12484 & 0.000154 & 0.015306 & 0.037338 & 0.015306 & 0.037338 \\
\hline b & -0.0259 & 0.007626 & -3.39657 & 0.004342 & -0.04226 & -0.00955 & -0.04226 & -0.00955 \\
\hline
\end{tabular}

Table 11. Stepwise regression for $\mathrm{CPH}$ treated beef nuggets among different parameters.

value of meat, bacterial load (both coliform and total bacterial count). As the $\mathrm{pH}$ value of the meat increased showed significant the count of total coliform and total bacterial count. Moreover, total coliform count is also positive associated with total bacterial count of the $\mathrm{CPH}$ treated meat during 15 days' storage. Total bacterial count as no association with color value of the meat like $\mathrm{L}$, a and $\mathrm{b}$ value. Color value of the meat showed significant association with a \& b value during the entire study duration and a value also showed the increased trend with the enhancement of $b$ value of treated meat.

\section{Conclusion}

The current research draws attention towards the fact that the use of different concentrations of the peptide powder can significantly affect the oxidative stability and functional properties of meat (beef) because of their well-known nutritional and health benefits. In this study, a weighed concentration of the dried milk casein protein hydrolysate $(\mathrm{CPH})$ powder was added to the raw beef nuggets in order to check their established effects on the oxidative stability as well as the functional capability of the minced beef during refrigeration storage. The $\mathrm{CPH}$ powder was added in the meat nuggets at different concentrations to check the effect of the peptide powder on oxidative stability and on the functional properties of ground beef made into nuggets at refrigeration temperature. The results acquired suggest that these anti-oxidant rich or biologically active compounds can effectively retard and or suppress the lipid-oxidation during the storage period. These casein protein hydrolysates exhibit potent anti-oxidant and anti-microbial properties. Results suggested that the buffalo milk casein could be used as a natural source of food protein to produce hydrolysates with higher anti-oxidant and anti-microbial activities. It also encourages the use of milk caseins and derived peptides for direct human consumption and as ample ingredients in reformulated and functional meat and meat products for enhancing their functionalities and shelf-life. Concisely, it can be concluded that the addition of bioactive peptides (BAP's) in beef nuggets have proved to be efficacious in improving the quality of meat. Its addition in meat or meat based products can help in curbing the deleterious quality effects along with storage of these products or the meat itself and hence can promote health which is the sole purpose of recent therapeutic food development researches and are indeed the need of hour.

\section{Data availability}

The data generated for this study available in the manuscript.

Received: 25 April 2020; Accepted: 9 November 2021

Published online: 24 January 2022

\section{References}

1. Singh, B. P., Vij, S. \& Hti, S. Functional significance of bioactive peptides derived from soybean. Peptides 54, 171-179 (2014).

2. Pogorzelska-Nowicka, E., Atanasov, A. G., Horbańczuk, J. \& Wierzbicka, A. Bioactive compounds in functional meat products. Molecules 23(2), 307 (2018).

3. Przybylski, M., Sun, S. \& Li, W. Development and characterization of a multi-layer magnetorheological elastomer isolator based on a Halbach array. Smart Mater. Struct. 25(10), 105015 (2016).

4. Lemes, A. et al. A review of the latest advances in encrypted bioactive peptides from protein-rich waste. Int. J. Mol. Sci. 17(6), 950 (2016).

5. Mohanty, D. P., Mohapatra, S., Misra, S. \& Sahu, P. S. Milk derived bioactive peptides and their impact on human health-A review. Saudi J. Biol. Sci. 23(5), 577-583 (2016).

6. Park, Y. W. \& Nam, M. S. Bioactive peptides in milk and dairy products: A review. Korean J. Food Sci. Anim. Resour. 35(6), 831 (2015).

7. Bazinet, L. \& Firdaous, L. Separation of bioactive peptides by membrane processes: Technologies and devices. Recent Pat. Biotechnol. 7(1), 9-27 (2013).

8. Hayes, M., Stanton, C., Fitzgerald, G. F. \& Ross, R. P. Putting microbes to work: Dairy fermentation, cell factories and bioactive peptides. Part II: Bioactive peptide functions. Biotechnol. J. Healthc. Nutr. Technol. 2(4), 435-449 (2007).

9. El-Salam, M. A. \& El-Shibiny, S. Bioactive peptides of buffalo, camel, goat, sheep, mare, and yak milks and milk products. Food Rev. Intl. 29(1), 1-23 (2013).

10. Haque, E., Chand, R. \& Kapila, S. Biofunctional properties of bioactive peptides of milk origin. Food Rev. Intl. 25(1), 28-43 (2008).

11. Moldes, A. B., Vecino, X., Cruz, J. M. Nutraceuticals and food additives. In Current Developments in Biotechnology and Bioengineering 143-164 (2017).

12. Wang, L. L. \& Xiong, Y. L. Inhibition of lipid oxidation in cooked beef patties by hydrolyzed potato protein is related to its reducing and radical scavenging ability. J. Agric. Food Chem. 53(23), 9186-9192 (2005).

13. Sarmadi, B. H. \& Ismail, A. Antioxidative peptides from food proteins: A review. Peptides 31(10), 1949-1956 (2010).

14. Pisoschi, A. M. \& Pop, A. The role of antioxidants in the chemistry of oxidative stress: A review. Eur. J. Med. Chem. 97, 55-74 (2015). 
15. Korhonen, H. \& Pihlanto, A. Technological options for the production of health-promoting proteins and peptides derived from milk and colostrum. Curr. Pharm. Des. 13(8), 829-843 (2007).

16. Kumar, D., Chatli, M. K., Singh, R., Mehta, N. \& Kumar, P. Antioxidant and antimicrobial activity of camel milk casein hydrolysates and its fractions. Small Rumin. Res. 139, 20-25 (2016).

17. Giménez, A., Ares, F. \& Ares, G. Sensory shelf-life estimation: A review of current methodological approaches. Food Res. Int. 49, $311-325$ (2012).

18. Suleria, H. A., Barrow, C. J. \& Dunshea, F. R. Screening and characterization of phenolic compounds and their antioxidant capacity in different fruit peels. Foods 9(9), 1206.S (2020).

19. Brand-Williams, W., Cuvelier, M. E. \& Berset, C. L. W. T. Use of a free radical method to evaluate antioxidant activity. LWT-Food Sci. Technol. 28(1), 25-30 (1995).

20. An, K. A., Arshad, M. S., Jo, Y., Chung, N. \& Kwon, J. H. E-beam irradiation for improving the microbiological quality of smoked duck meat with minimum effects on physicochemical properties during storage. J. Food Sci. 82(4), 865-872 (2017).

21. Shantha, N. C. \& Decker, E. A. Rapid, sensitive, iron-based spectrophotometric methods for determination of peroxide values of food lipids. J. AOAC Int. 77(2), 421-424 (1994).

22. Ahn, D. U. et al. Effect of muscle type, packaging, and irradiation on lipid oxidation, volatile production, and color in raw pork patties. Meat Sci. 49(1), 27-39 (1998)

23. Dave, D. \& Ghaly, A. E. Meat spoilage mechanisms and preservation techniques: A critical review. Am. J. Agric. Biol. Sci. 6(4), 486-510 (2011).

24. Holman, B. W., Collins, D., Kilgannon, A. K. \& Hopkins, D. L. The effect of technical replicate (repeats) on Nix Pro Color Sensor measurement precision for meat: A case-study on aged beef colour stability. Meat Sci. 135, 42-45 (2018).

25. Mancini, R. A. \& Hunt, M. Current research in meat color. Meat Sci. 71(1), 100-121 (2005).

26. AOAC (Association of Official Analytical Chemists). Official methods of analysis of the Association of Analytical Chemists International (2005).

27. Steel, R. \& Torrie, J. Principles and procedures of statistics: A biometrical approach MCGraw-Hill Book Company Toronto. Revi Veter 13(6), 481 (2012).

28. Sharma, H. et al. Use of various essential oils as bio preservatives and their effect on the quality of vacuum packaged fresh chicken sausages under frozen conditions. LWT-Food Sci. Technol. 81, 118-127 (2017).

29. Jin, S. K. et al. Development of sausages containing mechanically deboned chicken meat hydrolysates. J. Food Sci. 80(7), 1563-S1567 (2015).

30. Balakrishnan, B. et al. In vitro antioxidant and antibacterial properties of hydrolysed proteins of delimed tannery fleshings: Comparison of acid hydrolysis and fermentation methods. Biodegradation 22(2), 287-295 (2011).

31. Frankel, E. N. Recent advances in lipid oxidation. J. Sci. Food Agric 54, 495-511 (1991).

32. Yen, G. C., Chang, Y. C. \& Chen, J. P. Antioxidant activity of mycelia from Aspergillus candidus. J. Food Sci. 67, 567572 (2002).

33. Hernandez-Ledesma, B., Quiro, S. A., Amigo, L. \& Recio, I. Identification of bioactive peptides after digestion of human milk and infant formula with pepsin and pancreatin. Int. Dairy J. 17, 42-49 (2007).

34. AbuSaleem, A. \& Banaru, M. B. On almost contact metric hypersurfaces of nearly Kahlerian 6-sphere. Malays. J. Math. Sci. 8(1), $35-46$ (2014).

35. Wu, C. H., Chen, H. M. \& Shiau, C. Y. Free amino acids and peptides as related to antioxidant properties in protein hydrolysates of mackerel (Scomber austriasicus). Food Res. Int. 36, 949-957 (2003).

36. Li, X. X., Han, L. J. \& Chen, L. J. In vitro antioxidant activity of protein hydrolysates prepared from corn gluten meal. J. Sci. Food Agric. 88(9), 1660-1666 (2008).

37. Rudzińska, M., Flaczyk, E., Amarowicz, R., Wąsowicz, E. \& Korczak, J. Antioxidative effect of crackling hydrolysates during frozen storage of cooked pork meatballs. Eur. Food Res. Technol. 224(3), 293 (2007).

38. Istrati, D., Constantin, O., Ionescu, A., Vizireanu, C. \& Dinica, R. Study of the combined effect of spices and marination on beef meat vacuum packaged. The Annals of the University of Dunarea de Jos of Galati. Fascicle VI. Food Technol. 35(2), 75 (2011).

39. Rossini, K., Norena, C. P., Cladera-Olivera, F. \& Brandelli, A. Casein peptides with inhibitory activity on lipid oxidation in beef homogenates and mechanically deboned poultry meat. LWT-Food Sci. Technol. 42(4), 862-867 (2009).

40. Gray J. I. \& Pearson A. M. Rancidity and warmed-over flavor. Adv. Meat Res. 3, 221-269 (1987).

41. Fernández-Ginés, J. M., Fernández-López, J., Sayas-Barberá, E. \& Pérez-Alvarez, J. A. Meat products as functional foods: A review. J. Food Sci. 70(2), 37-43 (2005).

42. Verma, S. P. \& Sahoo, J. Improvement in the quality of ground chevon during refrigerated storage by tocopherol acetate preblending. Meat Sci. 56(4), 403-413 (2000).

43. American Meat Science Association. AMSA Meat Color Measurement Guidelines: AMSA. (American Meat Science Association, 2012)

44. Nieto, G. et al. Antioxidant and emulsifying properties of alcalase-hydrolyzed potato proteins in meat emulsions with different fat concentrations. Meat Sci. 83(1), 24-30 (2009).

45. Dekkers, E., Raghavan, S., Kristinsson, H. G. \& Marshall, M. R. Oxidative stability of mahi mahi red muscle dipped in tilapia protein hydrolysates. Food Chem. 124(2), 640-645 (2011).

46. Umuhumuza, L. C., Wei-min, N. \& Sun, X. Effect of Bovine lactoferrin and casein peptide powder on microbial growth and glucose utilization by microorganisms in pork meat during storage at $4{ }^{\circ} \mathrm{C}$. Pak. J. Nutr. 10, 208-213 (2011).

47. Prasanna, P. H. P., Grandison, A. S. \& Charalampopoulos, D. Effect of dairy-based protein sources and temperature on growth, acidification and exopolysaccharide production of Bifidobacterium strains in skim milk. Food Res. Int. 47(1), 6-12 (2012).

\section{Acknowledgements}

The authors are highly thankful to Ms. Tabassum Maqbool, Lecturer, Department of English Literature, Government College University Faisalabad, Pakistan for editing the manuscript.

\section{Author contributions}

The contribution of the each author for this manuscript was as follows, M.S.A. designed the experimental plan. G.H. conducted the analysis and drafted the manuscript, F.M.A. reviewed the manuscript. H.A.R.S. helped in revising and editing the manuscript. It is also confirmed that all the authors read and approved the final manuscript.

\section{Competing interests}

The authors declare no competing interests.

\section{Additional information}

Correspondence and requests for materials should be addressed to M.S.A. 
Reprints and permissions information is available at www.nature.com/reprints.

Publisher's note Springer Nature remains neutral with regard to jurisdictional claims in published maps and institutional affiliations.

(c) (i) Open Access This article is licensed under a Creative Commons Attribution 4.0 International License, which permits use, sharing, adaptation, distribution and reproduction in any medium or format, as long as you give appropriate credit to the original author(s) and the source, provide a link to the Creative Commons licence, and indicate if changes were made. The images or other third party material in this article are included in the article's Creative Commons licence, unless indicated otherwise in a credit line to the material. If material is not included in the article's Creative Commons licence and your intended use is not permitted by statutory regulation or exceeds the permitted use, you will need to obtain permission directly from the copyright holder. To view a copy of this licence, visit http://creativecommons.org/licenses/by/4.0/.

(C) The Author(s) 2022 